Article History:

Received: July 15, 2020

Revised: August 20, 2020

Accepted: August 24, 2020 https://doi.org/10.3126/pycnjm.v13i1.31496

PYC Nepal Journal of Management

Vol. XIII, No. 1, Page: 40-50

ISSN:2091-0258

\title{
Corporate Governance and Financial Performance of Nepalese Commercial Banks
}

\author{
Mohan Prasad Sapkota'
}

\begin{abstract}
This paper focuses on determining the relationship between corporate governance and financial performance of Nepalese commercial banks as well as examining the impact of corporate governance on banks performance. The sample consists of 9 commercial banks for the 10 year period of 2008/09 to 2017/18. Corporate governance is considered as leverage ratio, board meeting, board size and ownership concentration had mixed results on banks performance measured by ROE. Evidence indicates that debt ratio, net interest margin and total assets have significant positive contribution on banks performance. Board meeting and liquidity have negative impact on banks performance. However, board size and ownership concentration have no significant contribution to the firm performance.
\end{abstract}

Key words: assets, commercial banks, corporate governance, financial performance, and return

\section{BACKGROUND OF THE STUDY}

Corporate governance is the system of rules, practices and processes by which a company is directed and controlled. Corporate Governance is the mode through which entities are managed and governed (Yasser, Entebang \& Mansor; 2011). It balances the interest of major stakeholders like shareholders, management, suppliers, financiers, society, government, customers etc through rules, regulations, systems, procedures, activities and code of conducts so it can facilitate, handle and promote effective, entrepreneurial and prudent management that can deliver the long-term success of the organizations. Corporate governance act as a system of rules, regulations, responsibilities and obligations to its major stakeholders. Managers have incentives to expropriate a firm's assets by undertaking projects that benefit themselves personally but that impact shareholder wealth adversely (Jensen \& Meckling, 1976; Fama \& Jensen, 1983; and

1. Mr. Sapkota is a Lecturer at Birendra Multiple Campus, Chitwan, Tribhuvan University, Nepal.

He can be reached at mohansapkota24@gmail.com 
Shleifer \& Vishny, 1997). Corporate governance is a system of checks and balances between the board, management and investors to produce an efficiently functioning corporation, which increases the performance of the organization that ideally geared to produce long-term value to all stakeholders (Fahy, Roche \& Weiner; 2004). If managers take wrong decision, value of shareholders will lose while correct decision by them will also benefit themselves. Effective corporate governance reduces "control rights" stockholders and creditors confer on managers, increasing the probability that managers invest in positive net present value projects, (Shleifer \& Vishny, 1997), suggesting that bettergoverned firms have better operating performance through right decision at right time. Good corporate governance is centered on the principles of accountability, transparency, fairness and responsibility in the management of the firm that are the basic for success of the organization (Ehikioya; 2009). Corporate governance is related to accountability, transparency, fairness etc are the key to success of any organization.

Various problems have been seen in the corporate sectors as well as all sectors of the economy so the rising interest in corporate governance can be attributed to five reasons. (1) Worldwide privatization wave (2) Reforms in pension fund and growth in private savings (3) The 1980's takeover wave (4) Deregulation and integration of the capital markets world-wide and (5) Economic crises (Becht, Bolton \& Roell; 2002).

The corporate collapses resulting from a weak system of corporate governance highlighted the need to improve and reform the governance structure (Sharma \& Arora; 2016). The weak corporate governance leads to failure of the firm. Firms' governance plays an important role in the probability of accounting frauds and firms which have a weak governance structure are more prone to accounting frauds (Berkman, Zou \& Shaofeng; 2009).

The role of corporate governance in Nepalese firm is increasing day by day for effective performance. The monitoring and regulating bodies make various provisions and directives for corporate governance practices. Liquidation of several institutions (like Nepal Development Bank, Gurkha Development Bank, Bansbari Leather and Shoes, Samjhana Finance Company etc.). NRB has developed the corporate governance provisions and framework especially for financial institutions to regulate and supervise the BFIs.

Poudel \& Hovey (2013) concluded that bigger board and audit committee size and lower frequency of board meeting and lower proportion of institutional ownership lead to better efficiency in the commercial banks. Acharya (2013) concluded that there is no strong evidence of corporate governance is significant in determining firm valuation (using Tobin Q) in Nepal. Pradhan (2015) identified that Board size and executive CEO have significant effect on ROE but total asset has insignificant effect on ROE and concluded that there is a significant impact of corporate governance on ROE in the financial institutions mainly Commercial Banks. Gnawali (2018) found that corporate governance has played the significant role to the financial performance of Nepalese commercial banks measured by ROE. These mentioned studies in Nepalese perspectives shows the mixed results of firm performance by various corporate governance variables as well as these studies are unable to incorporate the block holding due to one or few number of shareholders hold 
the large volume shares that may affect the decision making process, interest margin is the main source of earning of banking industry, size of the firm determines the capability of the firm that may affect the performance of banking institutions, board meeting can influence the performance by increasing the cost and/or by contributing the additional or new or diverse decision. Hence, the following issues are arise like does board size and board meeting has significant impact on firm performance? Does net interest income have significant role on banks performance? Does block holdings have significant impact on firm performance?

\section{OBJECTIVES OF THE STUDY}

The basic objective of the study is to examine the impact of corporate governance that affects the financial performance measured by ROE of listed commercial banks of Nepal. The variables used in this study are leverage ratio, board size, board meeting, ownership concentration, net interest margin (NIM), firm size and liquidity. The overall objectives of this study as follows.

- To measure the relationship between corporate governance and financial performance of Nepalese commercial banks.

- To examine the impact of corporate governance on financial performance of Nepalese commercial banks.

\section{LITERATURE REVIEW}

Debt is the borrowing capital has a lowest source of capital (Modigliani \& Miller; 1963) and use of debt capital arise an agency issue which affects the proper operation of the organization (Jensen and Mackling, 1976). Ownership concentration is the large portion of shares held by one or few shareholders. Block holdings are important elements for controlling agency cost (Shleifer \& Vishny, 1986). High level of shareholdings might downsize the protection of interest of minority shareholding assumed that the presence of block holders might have a significant effect on firm financial performance. A shareholding of 5 percent or more of a company's stock is considered to be a significant constituting a block holding (Denis, 2001). Shleifer \& Vishny (1986) further argued that block holding of 5 percent shareholders try to maintain that level by transaction of shares if it fall below that level. Board size refers to the total number of directors that sits on the company's board. It is argued that within a certain range, the larger the board, the more effective it is in its statutory duties of monitoring the management. It is argued that within a certain range, the larger the board, the more effective it is in its statutory duties of monitoring the management (Sanda et al. 2005). There may be no one size-fits-all recommendation for what constitutes an optimal board size, a board size of 8-10 is often recommended by Yermack (1996). If board members are met regularly for meeting and discussion that result in good financial performances of the firm due to increase in the board members capacity for consultation, supervision and proper management (Ntim \& Osei, 2011). Short \& Keasey (1999) and Joh (2003) argued that larger firms have better opportunity 
than the smaller ones in creating and generating funds internally and accessing external resources as well as they further concluded that larger firms might benefit from economies of scale by creating entry barriers with a positive effect on firm performance. Larger the firm sizes larger number of stakeholders might be exist so performance of the firm might be affected. Bank profitability and liquidity has inverse relationship (Brigham \& Houston; 2007) due to banks hold liquid assets as an obligation to the requirements imposed by the authorities like NRB. Interest income is the major source of earning of banks. Generally, higher level of NIM leads to higher level of financial performance. Return on equity measures a corporation's profitability by revealing how much profit a company generates with the money shareholders have invested (Brigham \& Houston, 2007).

Abor (2005) identified the significantly positive relation between the ratios of shortterm debt to total assets, a negative relationship between the ratio of long-term debt to total assets and ROE as well as found that significantly positive association between the ratio of total debt to total assets and return on equity. Ebaid (2009) used multiple regression analysis and found that capital structure/ leverage choice decision, in general terms, has a weak-to-no impact on firm's performance. Ntim and Osei (2011) studied South African listed firms for the period of 2002 to 2007 and found that there is a positive relationship between board meeting frequency and firm performance. Aljifri \& Moustafa (2007) provided empirical data supporting a positive association between firm size and firm performance. Lipczinsky \& Wilson (2001) conducted a study and identified that new firms are anticipated to earn less profit than older ones because they are less experienced in the market and because they are trying to establish their own presence and trying to cover their cost structure. Lartey, Antwil \& Boadi (2013) conducted a study on liquidity and profitability using time series analysis on secondary data from the period of 2005 to 2010 and found that there was a very weak positive relationship between the liquidity and the profitability of the listed banks in Ghana. Putra, Hakim and Tambunan (2020) conducted a study and determined that interest margin has insignificant role for bank performance measured by ROA in Indonesia. The reliance on ROE as a performance measure is a key incentive to excessive risk-taking in banks (Moussu \& Petit-Romec, 2013).

\section{THEORETICAL FRAMEWORK}

Based on literature review, the relationship between corporate governance and firm performance is affected by several variables referred as control variables. Therefore, various control variables have been introduced to explain the variation of the firm performance. Independent variables affect the dependent variable as well the relationship between dependent and independent variables can also be affected by other variables called control variables. Hence, the impact of control variables is considered while determining dependent-independent variables relationship. These control variables are related to the firm's performance and corporate governance so these variables affect the firm performance. Finally, based on literature review, following theoretical framework has been developed for the study and presented in Figure 1. The short description of measurement of variables is presented in Table 1. 


\begin{tabular}{|l|l|l|}
\hline Independent Variables & \multicolumn{2}{|l|}{ Dependent Variables } \\
\hline $\begin{array}{l}\text { Leverage Ratio } \\
\text { Board Size } \\
\text { Ownership Concentration } \\
\text { Board Meetings }\end{array}$ & Firm Performance \\
\cline { 3 - 3 } & & ROE \\
\hline & $\begin{array}{l}\text { Control Variables } \\
\text { Firm Size } \\
\text { Net Interest Margin } \\
\text { Liquidity (LDR) }\end{array}$ \\
\hline
\end{tabular}

Figure 1. Theoretical framework

Table 1

Description and measurement of variables

\begin{tabular}{lll}
\hline ROE & Return on equity & $\begin{array}{l}\text { Net income after taxes divided by Common Equity or shareholders } \\
\text { equity on balance sheet. }\end{array}$ \\
\hline B Size & Board Size & Total number of board of directors in the banks. \\
\hline B Meeting & Board Meeting & Total no. of meeting conducted by banks during a year. \\
\hline OWC & $\begin{array}{l}\text { Ownership } \\
\text { Concentration }\end{array}$ & $\begin{array}{l}\text { Total percentage of shares held by shareholders of 5.00 percent } \\
\text { or more than 5.00 percent shares. }\end{array}$ \\
\hline F Size & Firm Size & $\begin{array}{l}\text { Natural log of Total Assets of firm in the balance sheet at year } \\
\text { end. }\end{array}$ \\
\hline LR & Leverage Ratio & $\begin{array}{l}\text { Total liabilities of balance sheet divided by total assets of balance } \\
\text { sheet at year end. }\end{array}$ \\
\hline LDR & Loan to Deposit Ratio & $\begin{array}{l}\text { Total loan or credit amount of balance sheet divided by total } \\
\text { deposit amount of balance sheet. }\end{array}$ \\
\hline
\end{tabular}

\section{RESEARCH METHODOLOGY}

Research methodology is the systematic process of reaching conclusion of the study. It determines the activities to be conducted to draw the result of the study. This study utilized descriptive, correlational and causal-comparative research design. The total population of the study is the total commercial banks (27 commercial banks till July, 2020) licensed by NRB and listed in Nepal stock exchange (NEPSE). Nine numbers of commercial banks is selected as a sample for the study using some criteria like operating more than ten years to till FY 2017/2018, not incurred losses during the study period, not inclusion of government banks due to direct influence by government and banks have no negative net worth. Secondary type of data is used for the study. Required data of the study is collected from their annual reports by downloading from their websites. Data of name list of banks and their operation date is taken from the NRB website. Data 
analysis is conducted using descriptive statistics, correlation analysis and regression analysis by regressing the firm's performance on various variables. Charts and ratios are employed for analysis and presentation of the results. SPSS and Microsoft Excel are used for required computation and analysis. The basic model of study is;

Performance $=f$ (Governance variables, Control variables, Dummies, $\left.\mathcal{E}_{j}\right)$

Governance variable is consider as leverage ratio, board size, board meeting and ownership concentration, control variables as firm size, liquidity, net interest margin and the error terms are used for the purpose of examining the impact of other variables which is not consider in this study. For detail study, following regression equations is developed and utilized.

Performance $=\beta_{0}+\beta_{1} L R+\beta_{2}$ B Size $+\beta_{3} B$ Meeting $+\beta_{4}$ OWC $+\beta_{5} L D R+\beta_{6} F$ $S I Z E+\beta_{7} N I M+\varepsilon_{i}$

Where,

Performance $=$ Performance is measured by ROE.

Independent Variables = leverage ratio, board size, board meeting and block shareholdings (ownership concentration).

Control variables $=$ Firm Size, Liquidity $($ LDR) and net interest margin (NIM)

The fitted model is appraised using F-statistics, R square, adjusted R Square, VIF, $\mathrm{D}-\mathrm{W}$ test for auto-correlation and $\mathrm{p}$ value and $\mathrm{K}-\mathrm{S}$ test of residuals are used.

This study is practicable for the commercial banking sectors under study so the results need not be applicable for other business industries or environments. This study is also unable to capture the governance score or index perspectives of corporate governance.

\section{RESULTS}

\section{Descriptive statistics}

Various descriptive statistics (mean, minimum, maximum, standard deviation etc) are employed to describe the phenomenon. The summary of descriptive statistics of all the variables used in this study is presented in Table 2.

The minimum value of ROE 8.40 percent and the maximum is 40.30 percent and the average is 19.90 percent. This performance variable indicates that their performance is not so fluctuate due to smaller standard deviation compared to mean. The average debt ratio is approximately 90 percent and average credit/loan to deposit ratio is 75 percent approximately. The minimum to maximum size of board and no. of board meeting is 5 to 9 members and 12 to 47 times. However, currently, NRB set the provision of 5 to 7 directors in the banking sector (The BAFIA 2017 strictly mentioned that board size should not exceed 7 (BAFIA; 2017). The average size of block holding is 53 percent approximately and the average net interest margin of sample banks is approximately 3.20 percent. The size of firm is measured in natural log of total assets of the firm is ranged from 23.29 to 25.87 with average of 24.716 . 
46 I PYC Nepal Journal of Management, August 2020 Vol. XIII, No. 1

Table 2

\section{Summary of descriptive statistics of the selected variables}

The table includes the summary of descriptive statistics of major variables used in the study. The results of sample of nine commercial banks for ten year period of 2008/09 to 2017/18 are presented. The ROE, LDR, LR, OWC, NIM are presented in fraction. F Size is presented in natural logarithm of the total assets. Year is presented as no. of years of the firm is operated. TQ is measured in times. Board size and board meeting are in absolute term.

\begin{tabular}{lccccc}
\hline Items & N & Minimum & Maximum & Mean & Std. Deviation \\
\hline Return on Equity (ROE) & 90 & 0.084 & 0.403 & 0.199 & 0.071 \\
Leverage Ratio (LR) & 90 & 0.834 & 0.945 & 0.904 & 0.024 \\
Loans to Deposit Ratio (LDR) & 90 & 0.387 & 0.942 & 0.748 & 0.118 \\
Board Size (B Size) & 90 & 5.000 & 9.000 & 7.160 & 1.016 \\
Board Meeting (B Meeting) & 90 & 12.000 & 47.000 & 18.760 & 7.785 \\
Ownership Concentration (OWC) & 90 & 0.000 & 0.796 & 0.533 & 0.256 \\
Net Interest Margin (NIM) & 90 & 0.005 & 0.048 & 0.032 & 0.007 \\
Firm Size (LN_TA) & 90 & 23.290 & 25.870 & 24.716 & 0.585 \\
Valid N (List wise) & 90 & & & & \\
\hline
\end{tabular}

\section{The correlation coefficient matrix}

The correlation coefficient measures the degree and direction of movements between variables. The correlation between financial performances, corporate governance and control variables are considered. The detail of correlation coefficient among variables is presented in Table 3.

\section{Table 3}

\section{Correlation coefficient among the variables}

The table includes the summary of correlation coefficient among the major variables used in the study. The results of sample of nine commercial banks for ten year period of 2008/09 to 2017/18 are considered. The ROE, LDR, LR, OWC, NIM are presented in fraction. F Size is presented in natural logarithm of the total assets. Board size and board meeting are in absolute term. Figure in the parentheses are the $p$-value.

\begin{tabular}{|c|c|c|c|c|c|c|c|c|}
\hline Items & ROE & LR & LDR & B Size & B Meet & OWC & NIM & F Size \\
\hline ROE & 1 & $\begin{array}{l}0.410^{* *} \\
(0.000)\end{array}$ & $\begin{array}{l}-0388^{* *} \\
(0.000)\end{array}$ & $\begin{array}{c}0.032 \\
(0.767)\end{array}$ & $\begin{array}{c}-0.352^{\star \star} \\
(0.001)\end{array}$ & $\begin{array}{l}0.471^{\star *} \\
(0.000)\end{array}$ & $\begin{array}{l}0.509^{\star *} \\
(0.000)\end{array}$ & $\begin{array}{c}0.207 \\
(0.050)\end{array}$ \\
\hline LR & & 1 & $\begin{array}{c}-0.400^{* *} \\
(0.000)\end{array}$ & $\begin{array}{l}0.438^{* *} \\
(0.000)\end{array}$ & $\begin{array}{l}-0.175 \\
(0.099)\end{array}$ & $\begin{array}{l}0.240^{*} \\
(0.023)\end{array}$ & $\begin{array}{l}-0.043 \\
(0.688)\end{array}$ & $\begin{array}{c}-0.374^{* *} \\
(0.000)\end{array}$ \\
\hline LDR & & & 1 & $\begin{array}{c}0.193 \\
(0.069)\end{array}$ & $\begin{array}{l}0.252^{*} \\
(0.017)\end{array}$ & $\begin{array}{l}-.477^{* *} \\
(0.000)\end{array}$ & $\begin{array}{c}0.016 \\
(0.884)\end{array}$ & $\begin{array}{l}-0.029 \\
(0.783)\end{array}$ \\
\hline B Size & & & & 1 & $\begin{array}{c}0.023 \\
(0.827)\end{array}$ & $\begin{array}{l}-0.131 \\
(0.220)\end{array}$ & $\begin{array}{l}-0.069 \\
(0.518)\end{array}$ & $\begin{array}{c}-0.322^{\star *} \\
(0.002)\end{array}$ \\
\hline B Meeting & & & & & 1 & $\begin{array}{c}-0.623^{\star *} \\
(0.000)\end{array}$ & $\begin{array}{l}-0.125 \\
(0.240)\end{array}$ & $\begin{array}{l}-0.078 \\
(0.466)\end{array}$ \\
\hline OWC & & & & & & 1 & $\begin{array}{l}0.227^{*} \\
(0.031)\end{array}$ & $\begin{array}{l}0.389^{* *} \\
(0.000)\end{array}$ \\
\hline NIM & & & & & & & 1 & $\begin{array}{c}0.173 \\
(0.103)\end{array}$ \\
\hline F Size & & & & & & & & 1 \\
\hline
\end{tabular}

**. Correlation is significant at the 0.01 level (2-tailed).

*. Correlation is significant at the 0.05 level (2-tailed). 
The Table 3 presents the correlation coefficient among all the study variables. The corporate governance and financial performance of firm is significant relation. The ROE had significant positive relationship among the LR, OWC and NIM while LDR and Board Meeting have negative relationship. Finally, except board size and firm size, all the study variables have significant relationship to the ROE.

\section{ROE and regression results}

By using regression model, the entire fitted models are statistically significant at the level of 5 percent. There is no problem of multicolinarity due to VIF lies below 10 of all coefficients of all equations. Based on Durbin Waston test, there is no serious autocorrelation. The final fitted model (inclusion of all variables) and is appraised using K-S test.

\section{Table 4}

\section{$R O E$ and regression results}

The table includes the summary of OLS coefficient of major variables included in the study. The results of sample of nine commercial banks for ten year period of 2008/09 to 2017/18 are considered. The dependent variable is ROE where exploratory variables are Leverage Ratio, Board size \& Meetings, OWC as well as control variables are NIM, LDR and F Size. The ROE, LDR, LR, OWC, NIM are presented in fraction. F Size is presented in natural logarithm of the total assets. Board size and board meeting are in absolute term. Figure in the parentheses are the $p$-value.

\begin{tabular}{lcccccc}
\hline & \multicolumn{5}{c}{ Model } \\
\cline { 2 - 7 } Items & 1 & 2 & 3 & 4 & 5 & 6 \\
\hline Constant & -0.741 & -0.581 & -0.730 & -1.942 & -1.838 & -1.884 \\
P Value & 0.006 & 0.076 & 0.008 & 0.000 & 0.000 & 0.001 \\
LR & 1.047 & 0.906 & 0.954 & 1.346 & 1.299 & 1.328 \\
P Value & 0.001 & 0.013 & 0.002 & 0.000 & 0.000 & 0.001 \\
VIF & 1.392 & 1.790 & 1.792 & 2.126 & 1.979 & 2.126 \\
B Size & -0.005 & -0.003 & -0.002 & 0.000 & 0.000 & -0.002 \\
P Value & 0.450 & 0.700 & 0.809 & 0.956 & 0.978 & 0.826 \\
VIF & 1.340 & 1.561 & 1.563 & 1.569 & 1.566 & 1.567 \\
B Meeting & -0.001 & -0.001 & -0.001 & -0.002 & -0.001 & -0.002 \\
P Value & 0.439 & 0.411 & 0.249 & 0.050 & 0.042 & 0.127 \\
VIF & 1.643 & 1.649 & 1.650 & 1.758 & 1.107 & 1.757 \\
OWC & 0.089 & 0.079 & 0.036 & -0.019 & & 0.019 \\
P Value & 0.009 & 0.027 & 0.236 & 0.559 & & 0.633 \\
VIF & 1.800 & 2.012 & 2.127 & 2.895 & & 2.801 \\
LDR & & -0.059 & -0.105 & -0.116 & -0.105 & -0.072 \\
P Value & & 0.403 & 0.079 & 0.042 & 0.049 & 0.292 \\
VIF & & 1.710 & 1.737 & 1.743 & 1.560 & 1.717 \\
NIM & & & 4.798 & 4.711 & 4.634 & \\
P Value & & & 0.000 & 0.000 & 0.000 & \\
VIF & & & 1.083 & 1.085 & 1.049 & \\
LN_TA & & & & 0.036 & 0.033 & 0.039 \\
P Value & & & & 0.002 & 0.001 & 0.006 \\
VIF & & & 1.740 & 1.278 & 2.801 \\
R & 0.569 & 0.574 & 0.737 & 0.771 & 0.770 & 0.624 \\
R Square & 0.324 & 0.329 & 0.543 & 0.595 & 0.593 & 0.389 \\
Adj. R Square & 0.292 & 0.290 & 0.510 & 0.560 & 0.563 & 0.345 \\
F Value & 10.177 & 8.255 & 16.422 & 17.183 & 20.149 & 8.816 \\
P Value & 0.000 & 0.000 & 0.000 & 0.000 & 0.000 & 0.000 \\
\hline
\end{tabular}


Based on $\mathrm{R}$ square, the minimum variation of ROE explained by exploratory and control variables are 32 percent (approx.) and maximum is 60 percent (approx.). However, adjusted $R$ square is calculated based on $R$ square from only those variables whose addition in the model which is significant. Hence, based on adjusted $R$ square, the range of variation in ROE explained by all variables is 29 to 56 percent. The ROE and the regression results are presented in Table 4.

The debt has positive impacts on ROE that may due to banks are able to utilize debt capital which is low cost source of capital through tax saving on interest. Board size has mixed impact on banks performance but all coefficients are insignificant at the level of 0.05 . Board meeting has inverse relation to the ROE. It means that increase in no. of board meeting is decrease the return to equity capital that may due to board meeting is unable to provide the significant contribution to the earnings to the equity holders (Sharma \& Arora; 2016). The ownership concentration has positive impact of banks performance that is the impact of block holders on banks performance is predictable for weak positive direction. Loans to deposit ratio (higher LDR downsize the liquidity) has inverse relation to ROE which tell that liquidity and profitability has positive relationship which may occurs due to easy payment of obligation as well as Nepalese commercial banks grab the market opportunity. Net interest margin has positive significant impact on ROE due to net interest income is the major source of net income for banking institutions. The impact of firm size on ROE is positive due to large firm is able to generate economics of scale. The residuals are normally distributed, there is no any pattern of residuals and are random and finally residuals are normally distributed with $p$ value of 0.571 .

\section{CONCLUSION AND DISCUSSION}

This study examine the relationship between corporate governance and firm performance. Similarly, this study also examines the effect of corporate governance on performance of Nepalese commercial banks. This study uses descriptive, correlational and causal comparative research design. There are total 27 commercial banks till June, 2020 but only 9 commercial banks are taken as a sample using various criteria. This study utilizes the secondary sources of data which covers the 10 year period of 2008/09 to $2017 / 18$. Model is summarized by $R$ square and adjusted $R$ square and validated by $F$ test as well as model is appraised by VIF, D-W test, plot and K-S test statistics.

This study found that leverage ratio had significant positive impact on ROE, board size had mixed but insignificant impact on ROE, board meeting had negative impact on banks performance but all coefficients are insignificant. Ownership concentration had mixed effect on bank performance measured by ROE. All the control variables had mixed results but NIM has significant positive impact on ROE due to the main source of income and profit of the banks is the interest income.

The leverage has positive impact on banks performance which is the consistent result with Abor (2005) that might due to low cost source and tax advantages on interest charge. The board size has negative impact on firm performance but has insignificant 
impact. This finding is contradicted with finding of Yasser, Entebang and Mansor (2011) that there is a positive and significant relationship between board size and ROE. Larger board size may unable to provide the new value to the organization so NRB limit the number of boards in the Nepalese banks and financial institutions. Frequency of board meeting has negative impact on firm performance and this result is contradict with Ntim and Osei (2011) that might due to inefficiency of large number of board meeting with internal conflict and associated cost. The size of the positively affect the performance of the Nepalese banks due to scale of economy and competitive advantages and this result is similar to the finding of Aljifri \& Moustafa (2007) study. The liquidity (LDR) has weak positive relation to ROE which is consistent to the finding of Lartey, Antwil \& Boadi (2013) that might due to take advantages in to investment opportunity into unfavorable economy. Net interest margin has significant positive impact on firm performance. This result contradicts with the finding of Putra, Hakim and Tambunan (2020). However, interest income is the main source of earning in the banking system so NIM has a significant positive impact on bank performance measured by ROE.

\section{REFERENCE}

Abor, J. (2005). The effect of capital structure on profitability: An empirical analysis of listed firms in Ghana. Journal of Risk Finance, 6(5), 438-445. doi.org/10.1108/15265940510633505

Acharya, R. (2013). Corporate governance and firm performance in Nepal. Nepalese Academy of Management, Kathmandu, Nepal, 1(1), 21-46.

Aljifri, K., \& Moustafa, M. (2007). The Impact of corporate governance mechanisms on the performance of UAE Firms: An empirical analysis. Journal of Economic and Administrative Sciences, 23(2), 71-93. doi.org/10.1108/10264116200700008

Becht, M., Bolton, P., \& Roell, A. (2002). Corporate governance and control. ECGI Working Paper Series in Finance No 02/2002. doi.org/10.2139/ssrn.343461

Berkman.H., Zou, L., \& Shaofeng, G. (2009). Corporate governance, profit manipulation and stock return. Journal of International Business and Economics, 9(2), 132-145. Retrieved from: http://www.nber.org/papers/w9371

Brigham, E. F., \& Houston, J. F. (2007). Fundamentals of financial management. United State of America: Thomson Publication

Ebaid, I. (2009). The impact of capital structure choice on firm performance: Empirical evidence from Egypt. Journal of Risk Finance, 10(5), 477-487. doi.10.1108/15265940911001385

Ehikioya, B. I. (2009). Corporate governance structure and firm performance in developing economies: Evidence from Nigeria. Corporate Governance: The International Journal of Business in Society, 9(3), 231-243. doi.org/10.1108/14720700910964307

Fahy, M., Roche, J., \& Weiner, A. (2004): Beyond governance -creating corporate value through performance, conformance and responsibility. England: John Wiley \& Sons.

Fama, E. F., \& Jensen, M. C. (1983). Separation of ownership and control. Journal of Law and Economics, 15(2), 301-325. doi.org/10.1086/467037

Gnawali, A. (2018). Corporate governance and its impact on financial performance in Nepalese Commercial Banks. International Journal of Modern Research in Engineering \& Management (IJMREM), 1(7), 41-51.

Jensen, M., \& Meckling, W. (1976). Theory of the firm: Managerial behavior, agency costs and ownership structure. Journal of Financial Economics, 3(4), 305-360. 
Joh, S. W. (2003). Corporate governance and firm profitability: Evidence from Korea before the economic crisis. Journal of Financial Economics, 68(2), 287-322.

Lartey, V. C., Antwil, S., \& Boadi, E. K. (2013). The relationship between liquidity and profitability of listed banks in Ghana. International Journal of Business and Social Science, 4(3), 48-56.

Lipczynski, J., \& Wilson, J. (2001). Industrial organization. Edinburgh Gate:Prentice Hall.

Modigliani, F., \& Miller. H. M. (1963). Corporate income taxes and the cost of capital: A correction. The American Economic Review, 53(3) 433-443.

Moussu C., \& Petit-Romec A. (2013). ROE in banks: Myth and reality. Conference Paper, 1-32. Retrieved from: SSRN 2374068, 2014 - papers.ssrn.com

Ntim, C., \& Osei, K. A. (2011). The impact of corporate board meetings on corporate performance in South Africa. African Review of Economics and Finance, 2(2), 83-103.

Poudel R. P. S., \& Hovey, M., (2013). Corporate governance and efficiency in Nepalese commercial banks. International Review of Business Research Papers, 9(4), 53 - 64. doi.org/10.2139/ssrn.2163250

Pradhan, R. S., (2015). Corporate governance and bank performance in Nepal. Retrieve from: SSRN: https://ssrn.com/abstract=2793445 or http://dx.doi.org/10.2139/ssrn.2793445.

Putra, F. A., Hakim, D. B., \& Tambunan, M. E. (2020). Determinant analysis of net interest margin and banking profitability in Indonesia. International Journal of Science and Research (IJSR), 9(1), 174-180. Retrieved from: Research Gate Impact Factor (2018): 0.28 | SJIF (2018): 7.426

Sanda, A., Mikailu, A. S., \& Garba, T. (2005). Corporate governance mechanisms and firm financial performance in Nigeria. African Economic Research Consortium, 149, 1-47

Sharma, A., \& Arora, C., (2016). Corporate governance and firm performance in developing countries: Evidence from India corporate governance. The International Journal of Business in Society, 16(2), 420-436. doi.org/10.1108/CG-01-2016-0018

Shleifer, A., \& Vishny, R. (1986). Large shareholders and corporate control.Journal of Political Economy, 94(3), 461-488.

Shleifer, A., \& Vishny, R. W. (1997). A survey of corporate governance. National Bureau of Economic Research, Working paper 5554, 1-80.

Short, H., Keasey, K., Wright, M., \& Hull, A. (1999). Corporate governance: From accountability to enterprise. Accounting and Business Research, 29(4), 337-352.

Yasser Q. R., Entebang H., \& Mansor, S. A. (2011). Corporate governance and firm performance in Pakistan: The case of Karachi Stock Exchange (KSE)-30.Journal of Economics and International Finance, 3(8), 482-491. Retrieve from: http://www.academicjournals.org/JEIF

Yermack, D. (1996). Higher market valuation of companies with a small board of directors. Journal of Financial Economics, 40(1996), 185-211. 